Article

\title{
Gender Factors and Inclusive Economic Growth: The Silent Revolution
}

\author{
Laura Cabeza-García ${ }^{1}{ }^{*}$, Esther B. Del Brio ${ }^{2}$ and Mery Luz Oscanoa-Victorio ${ }^{3}$ \\ 1 Department of Business Management, University of León, 24071 León, Spain \\ 2 IME, Center of Women Studies, University of Salamanca, 37007 Salamanca, Spain; estherdelbrio@gmail.com \\ 3 School of Economics, Universidad Nacional Daniel Alcides Carrión, 0051063 Pasco, Peru; \\ meryluz257@hotmail.com \\ * Correspondence: laura.cabeza@unileon.es; Tel.: +34-987-293-496
}

Received: 30 October 2017; Accepted: 2 January 2018; Published: 6 January 2018

\begin{abstract}
The gender factors that trigger economic growth in both high- and low-income countries were investigated in this study. To address these gender factors, four characteristic dimensions of gender inclusion were considered: education, access to the labor market, fertility, and democracy. The relationship between economic growth and gender factors was analyzed in a sample of 127 countries. Value and robustness were added to the results using dynamic models applied to panel data while accounting for endogeneity. We conclude that high fertility in women has negative effects on economic growth. However, when women have greater access to secondary education and the labor market in conditions of equality, the effects are positive. Similarly, the access of women to active political participation has significant effects on economic growth. Overall, this study helps identify which gender factors may promote inclusive economic growth, which is economic growth achieved when both men and women are incorporated in equal conditions.
\end{abstract}

Keywords: gender factors; inclusive economic growth; education; labor force; fertility; democracy

\section{Introduction}

The study of gender equality and its impact on social, political, and economic aspects is a constant theme in the literature, due to the efforts in the social and political arenas to incorporate women in the different decision-making areas under conditions of equality with men. Our analysis was conducted on the impact of gender factors on the economic growth in different nations. To define economic growth from an inclusive perspective, we defined the term "inclusive economic growth" for the first time in the literature. Inclusive economic growth means that the effort to advance a country's growth and development should be produced with the contribution of all citizens without excluding an important group of the society, more specifically, women. Considering the assessment that "gender equality brings about economic growth but economic growth does not necessarily bring about gender equality" [1], we focused on the gender factors that trigger an increase in and stimulate economic growth in a country, for both low and high income countries, and thus result in inclusive economic growth.

The study of economic growth and its factors have been a constant in economic history. Different models have tried to clarify the factors that explain economic growth. A previous study [2] supported exogenous factors and attributed economic growth to the accumulation of capital, which was only achieved through saving. Subsequently, the models have been improved [3] by including endogenous factors and highlighting the role of human capital and technology as key indicators of growth.

Paradigm shifts have incorporated new variables into the growth models, highlighting certain variables, such as the level of corruption perceived by citizens, political conflicts, population in rural areas, and many others. A surge of factors related to gender have emerged, coinciding with the expansion of gender research in other disciplines. A small sample of these gender variables include 
the existence of quota systems or positive laws that favor the participation of women in different decision-making bodies; the educational level of women; the fertility of adult women or adolescent women; the participation of women in governing bodies, including female directors or advisors in companies and women in the political arena; women in competitive areas, such as sports; and the effect of women on the culture of a country.

The concept of 'gender' has acquired outstanding protagonism in different social areas, as it is considered an elemental and strategic principle in development policy. These policies stress the need to ensure equal opportunity in the processes of human development as a fundamental element for achieving equitable and sustainable development, and growth for all [4]. This is the philosophy that underlies our paper and which aimed to determine which gender variables favor inclusive and sustained economic growth of a country. Previous studies have examined the relationship between gender factors and economic growth. A significant number of studies showed that, on a micro level, gender gaps negatively affect macroeconomic results and economic growth, and that the influence of gender factors on economic growth seems to be determined by variables such as the economic system, education of women, distribution of work between sexes, and political regime [5-9].

However, other studies investigated the effects of gender gaps, determining that the higher the gap, the higher the economic growth [10-12] by keeping women in a role that balances the family, favors the education of the children, and reduces the available labor force. These results are obviously solely based on economic reasons and the concept of inclusive economic development, where economic efficiency should be obtained, while respecting human rights and defending the equality of women in accessing the same rights as their male peers. A third group of studies [13] found the significance of the relationship between the gender gap and economic growth varied according to whether the impact was measured in the short or long term.

Regardless, the understanding and quantification of the economic importance of gender factors in their different dimensions-including education, employment, fertility, democracy, and technology, as well as the quantification of their effects on the economic growth and how the economic growth helps to reduce these gaps-are a basic question for gender research and advances in equality. This is important from an academic perspective, but even more so in the political sphere to facilitate decision-making that favors economic growth and the equitable distribution of profits between men and women. This equitable distribution is what we term 'inclusive economic growth' in this paper.

The aim of this paper was to analyze the effects that gender factors produce on a country's economic growth from a macroeconomic perspective, considering different gender dimensions: female education, female labor force, fertility, and access of women to the political arena (democracy). Previous literature analyzed some of these female dimensions. To the best of our knowledge, this is the first investigation that incorporates all these dimensions into the same model. To accomplish this, we conducted an empirical study from an international database, rarely used in previous studies. The study was based on a robust methodology that applies panel data and dynamic models such as the Generalized Method of Moments (GMM), allowing us to control for the endogeneity inherent in the model as well as the unobservable heterogeneity (country effects) by using the first differences for all the variables. Using this method, we wanted to offer robust, current, and timely results on the link between the inclusion of women and economic growth in a globalized and multi-country environment.

The results obtained from a sample of 127 countries lead to the conclusion that high female fertility has negative effects on economic growth. However, when women have greater access to secondary education and to the labor market, the effects are positive. The effects are also positive when women have access to active political participation.

\section{Literature Review on Effects of Gender Factors on Economic Growth: Hypotheses Statement}

\subsection{Economic Growth and Access of Women to Education}

The relationship between the education levels of women and economic growth has been previously studied, with contradictory results, since evidence exists for both a negative and positive 
relationship $[14,15]$. The education gender gap was found to block economic growth and significantly reduce GDP, when modelled theoretically $[12,16,17]$. The gender gap in education was also found to have a negative impact on economic growth in a subsequent period [18-21]. Therefore, an increase in the educational level of women is supported as a form of increasing economic growth. Regardless, the opposite situation has been defended [22,23], one of which was with a Pakistani sample.

Several focuses are possible for the analysis of the relationship between educating women and economic growth, which could explain these different results. The majority of the authors considered the effects of female education on the creation of employment in that same generation, that is, in the short term, whereas others [21] analyzed the impact of female education on the following generation. In the first case, the effect of female education was analyzed based on their training and qualification as labor, and how this affects growth. In the second case, the effect of female education on fertility was examined in the long term. The negative impact of education on female fertility resulted in a negative impact on the creation of human capital in the following generation and, therefore, a reduction in long-term economic growth [24].

Different focuses based on the variable used can also measure the education level of women. Thus, we found papers that used the access of women to primary education measured by the number of girls in school, or the access of women to secondary education. Few studies measured the access of women to university, although a positive relationship between economic growth and university studies was identified [25]. In addition, some studies analyzed both the educational level of women and men. Female secondary education has been shown to be positively associated with growth $[10,26,27]$, whereas the impact of male education was negatively but not significantly associated. Conversely, male education was observed to have a positive relationship with economic growth, whereas female education had a negative relationship [22,23].

Studies have suggested that increasing female education results in greater economic growth as long as these women represent an increase in qualified labor $[10,11,28]$. These studies are consistent with another that used micro data to show that girls have a superior marginal performance in education, meaning that educating women generates more additional profitability than educating men [7].

The education of girls was argued to have a "catalytic effect" in all the dimensions of economic development, including a higher level of productivity and encouraging economic growth [29]. The increase in the quantity of education and employment of women was shown to broaden the available talent pool in an economy, increase the income of women, and produce GDP growth [30]. Similarly, other studies indicated that the gender inequality in education reduces the average amount of human capital in a society and, therefore, harms economic growth $[9,15,18,19,21,24,31]$.

In view of the above arguments, we present the following hypothesis:

Hypothesis 1 (H1). With a higher educational level of women, greater economic growth is expected.

\subsection{Economic Growth and the Female Labor Force}

Since the Second World War, one of the most notable changes in the labor markets is the increase of women in the labor market. In the U.S.A., the employment rate of women of working age has doubled from approximately $35 \%$ in 1945 to $77 \%$ at the end of the century. Similar trends have been detected in most Organization for Economic Co-operation and Development (OECD) countries [32]. Despite this increase, important obstacles to the integration of women into the working world still exist in different economies [33].

Some authors have concentrated their research on analyzing the consequences of the gender labor gap on economic growth. The majority of them, with few exceptions, have found a positive relationship between the greater access of women to employment and economic growth [23,34-36], which should encourage public and private institutions to incentivize female employment.

Two measures of inequality have been used: the proportion of women participating in the overall labor force, and the proportion of the female population of working age in formal employment [25,37]. 
The proportion of women in formal employment was found to have a positive and significant impact on economic growth [37]. Gender differences in education were thought to lead automatically to gender differences in employment, particularly in the formal sector, where the employers would prefer workers with good training and, therefore, would not consider applications from women without education [9,24]. Conversely, if large barriers exist for women to access employment, the parents might decide that educating girls is not sufficiently lucrative and beneficial for the family, thereby producing a lower educational demand for women, resulting in a greater gender gap in education. Thus, gender differences in education and employment are closely related to each other and separating the effects of one from the other is difficult. This is the reason why models that control for endogeneity are required. These same difficulties were encountered in a model that suggested that gender inequality in employment is associated with higher levels of fertility, which is determined by the lack of education of girls, which in turn reduces economic growth [38].

Economic growth is triggered by the access of women to the labor force only when they are rewarded by low salaries, thus promoting the gender wage gap [39]. The access of women to the labor force not only increases economic growth, but also stimulates social welfare and human rights, causing the authors to demand positive laws promoting gender equality [30].

Based on these arguments, the following hypothesis is posed:

Hypothesis 2 (H2). With a higher participation of women in the labor market, greater economic growth is expected.

\subsection{Economic Growth and Fertility}

Prior evidence uncovered the existence of a "demographic dividend" and a window of opportunity for economic growth as a result of fecundity decreases $[40,41]$. This demographic dividend is basically due to the decrease in rates of juvenile dependence, increasing the percentage of active population. So, the decrease in fecundity leads to changes in behavior that are translated into higher income. For example, the changes in fertility and the age structure can affect the rates of national savings and investment [42,43], and increase productivity by improving the health and education of each child [41,44-48]. Lower fertility can induce higher rates of business activity or employment for women [49], especially for low-income countries. Many papers have thoroughly analyzed fertility and economic growth. The relevant role of fertility and the demographic transition have been stressed to contribute to the successful economic growth of Eastern Asia [50].

The interrelations are crucial, since the decrease in fertility is initiated by incorporating women into the education system. With women accessing more education, the possibilities for a country to begin a demographic transition of decreasing fertility increase, providing a path to economic growth. By decreasing the number of children and increasing the number of young workers, and supposing that salaries do not increase, the young labor force tends to increase and generate a positive impact on the growth of the economy. The underlying idea is that the rapid growth of the population produces an exhaustion of resources, dilution of capital due to the rapid growth of the labor force, urbanization, and reductions in the rate of savings caused by a large dependent population [51].

Fertility negatively and significantly influencing the rate of growth of the GDP has been confirmed [52], whereas fertility and the income per capita have been shown to be positively associated in the majority of high-income OECD countries [53]. This relationship is also produced when salaries increase, the salary gap persists [53], and the results of fertility are translated into higher salaries for women [54]. The necessity of good social planning so that fertility significantly raises the production per capita has been demonstrated [55-57].

Still, supporters of the existence of a negative relationship between fertility and economic growth exist $[53,58,59]$. In the first two studies, fertility was negatively correlated to economic growth for low-income countries. However, the once-negative association between fertility and economic growth has become positive for OECD economies with high levels of income per capita [59]. 
Notably, in countries where the fertility rate has radically decreased in recent decades and family life is not emphasized, such as in Spain or France, the relationship is positive, and governments have had to advocate measures to increase birth rates to maintain pension systems and future growth.

Overall, the economic literature mostly supports a negative relationship, so this is reflected in our hypothesis.

Hypothesis 3 (H3). With higher fertility and fecundity, lower economic growth is expected.

\subsection{Economic Growth and Democracy}

Early research on the relationship between economic growth and democracy [60-62] underscored a positive relationship between the two variables. With the democratization of countries in Latin America and Eastern Europe [63], and a simultaneous increase in economic liberalization, this positive relationship between economic development and democracy was observed [64-66]. The passing of time has permitted a retrospective view, thus leading to the conclusion that the growth of a country is directly influenced by the number of years it has existed and the quality of its democracy [67].

For the participation of women in political life, the evidence shows that participation in bodies of power and institutions is predominantly masculine, whereas voluntary associations, organizations, and "informal" community politics tend to be led by women. According to the data [68], the gender differences in political participation are present in many countries and do not visibly diminish as the countries become richer. The participation is even less in low-income countries. In a sample of 16 Latin American countries, including 15,828 municipalities, only 5.3\% were headed by women [69]. This occurs despite the fact that the political representation of women can have an immediate positive influence on the level of democracy in a country due to being a direct measure of gender equality and human rights $[70,71]$.

Furthermore, a greater proportion of women with legislative power would help introduce new policies for social and economic development that also empower women. These polices include establishing gender quotas, redirecting the distribution of wealth, and eliminating discrimination against women, since women know the many difficulties they faced to dedicate themselves to politics [30,33,72].

For the existence of a positive relationship between the presence of women in parliament and economic growth, little empirical evidence is available. The two relevant studies were both for Asian countries [73,74]. In both cases, their conclusions were clear cut, "it is evident that high representation of women in parliament has simulated economic growth". A similar conclusion was attained in one other study [75].

Given this scenario, our last hypothesis is posed:

Hypothesis 4 (H4). With the greater participation of women in the democratic system, a greater economic increase is expected.

\section{Sample Variables and Methodology}

\subsection{Sample}

To test our hypotheses, we built a panel containing both high and low income markets for the period of 2000 to 2014. Data were obtained from The World Bank DataBank, which contains collections of time series data on a variety of topics for many countries. We were able to build a panel including 127 countries and 1905 observations. However, the econometric technique we used, the Generalized Method of Moments (GMM), requires information to be available for at least four consecutive years per country to test the absence of second-order serial correlation. In addition, due to some missing values in some of the variables, we obtained an unbalanced panel of 1718 observations for 127 countries over 15 years. 


\subsection{Variables and Methodology}

The variables used in the analysis are shown in Table 1. For the methodology, we used a panel data methodology to estimate our models. We used the two-step difference GMM model for dynamic panel data models that was created previously [76]. Unlike cross-sectional analysis, the dynamic panel data analysis is a more robust methodology that allowed us to control for individual heterogeneity or unobservable individual effects (country effects) by considering first differences and control for an endogeneity problem. In addition, to the best of our knowledge, our study is the first related to inclusive growth that applied a panel data methodology.

Table 1. Definition of variables.

\begin{tabular}{|c|c|}
\hline \multicolumn{2}{|r|}{ Panel A: Dependent Variable } \\
\hline Variable & Description \\
\hline GDP & $\begin{array}{l}\text { Annual percentage growth rate of GDP. Aggregates are based on constant } 2010 \\
\text { U.S. dollars. GDP is the sum of gross value added by all resident producers in } \\
\text { the economy, plus any product taxes, minus any subsidies not included in the } \\
\text { value of the products. It is calculated without making deductions for the } \\
\text { depreciation of fabricated assets or for depletion and degradation of natural } \\
\text { resources }[77,78] \text {. }\end{array}$ \\
\hline \multicolumn{2}{|r|}{ Panel B: Explanatory and Control Variables } \\
\hline \multicolumn{2}{|r|}{ Explanatory Variables } \\
\hline EDUCATION & $\begin{array}{l}\text { Percentage of female students enrolled in all secondary education programs in } \\
\text { a given school year }[17,25] \text {. }\end{array}$ \\
\hline FEMALE_LABOR & $\begin{array}{l}\text { The extent to which women are active in the labor force (\%). Labor force } \\
\text { includes people aged } 15 \text { and older who meet the international labor } \\
\text { organization's definition of the economically active population }[33,36] \text {. }\end{array}$ \\
\hline FERTILITY & $\begin{array}{l}\text { The number of children that would be born to a woman if she were to live to } \\
\text { the end of her childbearing years and bear children in accordance with current } \\
\text { age-specific fertility rates [51]. }\end{array}$ \\
\hline DEMOCRACY & $\begin{array}{l}\text { Women in parliament as the percentage of parliamentary seats in a single or } \\
\text { lower chamber held by women [71]. }\end{array}$ \\
\hline \multicolumn{2}{|r|}{ Control Variables } \\
\hline LABOR_FORCE & $\begin{array}{l}\text { The proportion of the population aged } 15 \text { and older that is economically active: } \\
\text { all people who supply labor for the production of goods and services during } \\
\text { a specified period. }\end{array}$ \\
\hline TECHNOLOGY & $\begin{array}{l}\text { Expenditures for research and development are current and capital } \\
\text { expenditures (both public and private) on creative work systematically } \\
\text { undertaken to increase knowledge, including knowledge of humanity, culture, } \\
\text { and society, and the use of knowledge for new applications. Research and } \\
\text { development (R\&D) covers basic research, applied research, and experimental } \\
\text { development, measured it as percentage of GPD. We used R\&D expenses as } \\
\text { a proxy for technological change since it is the most exigent variable in terms of } \\
\text { differences among countries and because R\&D expenses also have a specific } \\
\text { impact on female studies. }\end{array}$ \\
\hline COUNTRY & Dummy variable that equals one for low-income countries and zero otherwise. \\
\hline CRISIS & Dummy variable that equals one for years 2008-2014 and zero otherwise. \\
\hline
\end{tabular}

The GMM estimator uses internal instruments. These instruments are based on lagged values of the explanatory variables that may present problems of endogeneity. Only the economic situation was considered exogenous. More precisely, we used all the endogenous right-hand-side variables in the model lagged from $\mathrm{t}-1$ to $\mathrm{t}-4$ for equations in differences. 
To check the validity of the model specification when using GMM, we used Hansen's statistic of over-identifying restrictions. Hansen's statistic tests for the absence of correlation between the instruments and the error term. We also included $\mathrm{m}_{2}$ statistics to verify the lack of second-order serial correlation in the first-difference residuals. In addition to these specification contrasts, the following Wald test was included in the estimations: $z_{1}$ of the joint significance of the reported coefficients. Additionally, we corrected the estimations for heteroscedasticity problems by using the option robust for the 'xtabond2' command of the Stata program.

Specifically, the general panel data dynamic model to be tested, shown in Figure 1, is as follows:

$$
G D P_{i t}=a_{0}+\beta X_{i t}+\gamma_{i}+\mu_{i t}
$$

where $i$ indexes the country, $t$ indexes time, $X$ denotes the explanatory and control variables, and $\gamma_{i}$ is the firm's effect, that we assume constant for firm $i$ during period $t$, and $\mu_{i t}$ is the error term.

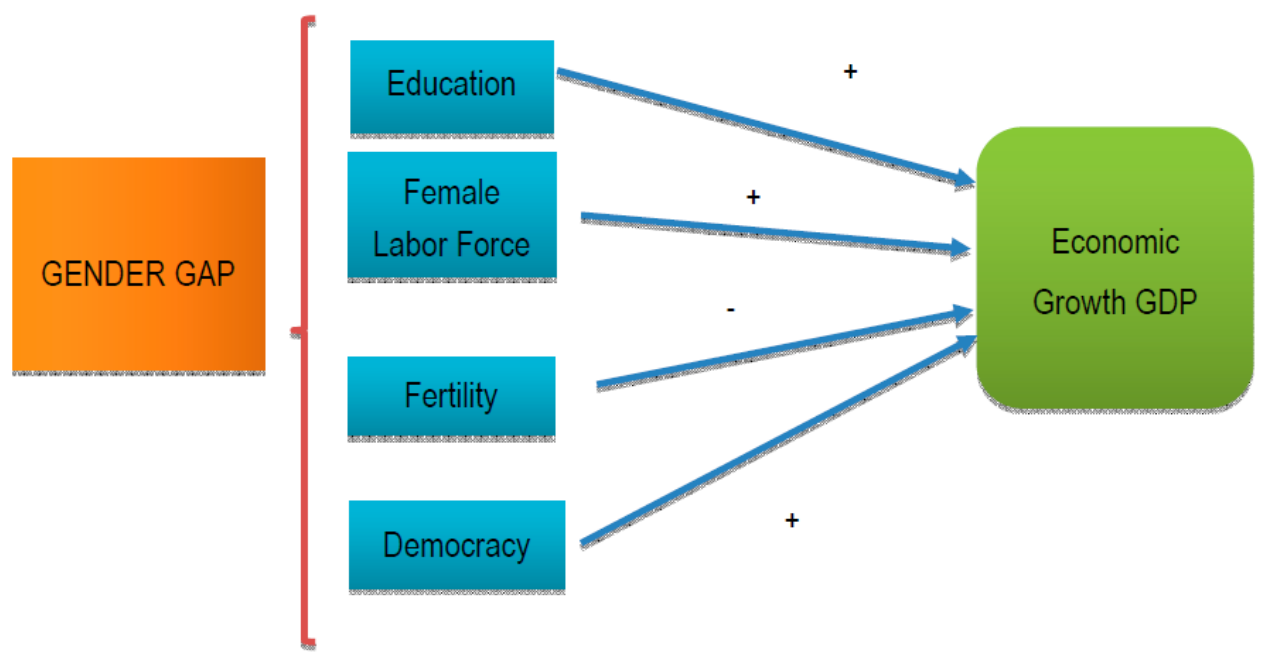

Figure 1. Research model.

\section{Results}

Before completing the GMM analysis, Table 2 presents the main descriptive statistics. The average annual GDP growth rate is $4.079 \%$. Nearly $41 \%$ of the women were enrolled in all secondary programs and $39 \%$ of the women met the international labor organization's definition of being an economically active population. However, only $16 \%$ of women held a seat in parliament.

Table 2. Summary statistics $(n=1846)$.

\begin{tabular}{ccccc}
\hline \multicolumn{5}{c}{ Panel A: Continuous Variables } \\
\hline Variable & Min. & Max. & Mean & SD \\
GDP & -62.076 & 104.487 & 4.079 & 5.129 \\
EDUCATION & 0 & 58.136 & 41.001 & 17.469 \\
FEMALE_LABOR & 0 & 51.810 & 39.464 & 11.417 \\
FERTILITY & 0 & 7.354 & 2.686 & 1.464 \\
DEMOCRACY & 0 & 53.1 & 16.362 & 10.874 \\
LABOR_FORCE & 0 & 89.6 & 60.972 & 14.264 \\
TECHNOLOGY & 0 & 4.523 & 0.601 & 0.934 \\
\hline Panel B: Dummy Variables & \multicolumn{5}{c}{ Frequency $(\%)$} \\
\hline COUNTRY & 1356 & $(73.43 \%)$ \\
CRISIS & 835 & $(45.23 \%)$ \\
\hline
\end{tabular}


Table 3 lists the correlation coefficients of the variables used in the panel data estimations. Although some variables showed a statistically significant correlation, an analysis of the variance inflation factors (VIF) revealed no evidence of multicollinearity, as all of them remained below 10 [79].

Table 3. Correlation matrix for the dependent and explanatory variables.

\begin{tabular}{ccccccccc}
\hline Variable & $\mathbf{1}$ & $\mathbf{2}$ & $\mathbf{3}$ & $\mathbf{4}$ & $\mathbf{5}$ & $\mathbf{6}$ & $\mathbf{7}$ & $\mathbf{8}$ \\
\hline 1. GDP & 1 & & & & & & \\
2. EDUCATION & $-0.101^{* * *}$ & 1 & & & & & \\
3. FEMALE_LABOR & 0.006 & -0.013 & 1 & & & & \\
4. FERTIITY & $0.122^{* * *}$ & $-0.319^{* * *}$ & 0.007 & 1 & & & \\
5. DEMOCRACY & $-0.131^{* * *}$ & $0.138^{* * *}$ & $0.295^{* * *}$ & $-0.244^{* * *}$ & 1 & & \\
6. LABOR_FORCE & $0.134^{* * *}$ & $-0.136^{* * *}$ & $0.684^{* * *}$ & $0.321^{* * *}$ & $0.096^{* * *}$ & 1 & \\
7. TECHNOLOGY & $-0.177^{* * *}$ & $0.218^{* * *}$ & $0.278^{* * *}$ & $-0.398^{* * *}$ & $0.381^{* * *}$ & -0.015 & 1 \\
8. COUNTRY & $0.090^{* * *}$ & $-0.101^{* * *}$ & $-0.132^{* * *}$ & $0.183^{* * *}$ & $-0.043^{*}$ & $0.061^{* * *}$ & $-0.467^{* * *}$ & 1 \\
9. CRISIS & $-0.202^{* * *}$ & -0.032 & $0.052^{*}$ & $-0.069^{* * *}$ & $0.249^{* * *}$ & 0.038 & $0.059^{* *}$ & $0.557^{* * *}$ \\
\hline
\end{tabular}

Note: $(p$-value $) *$ Statistically significant at a 0.1 level; ${ }^{* *}$ Statistically significant at a 0.05 level; ${ }^{* *}$ Statistically significant at a 0.01 level.

Table 4 summarizes the results of the multivariate analysis to study the causal relationships proposed. These results were obtained using the STATA12 program. In support of $\mathrm{H} 1$, the results show that female education (EDUCATION) significantly increased the country's economic growth $(\beta=0.021$; $p=0.044)$. These results are in line with other previous studies [25] that suggested increasing the level of female education increases economic growth.

Table 4. Generalized method of moments (GMM) results.

\begin{tabular}{ccc}
\hline Variable & Coefficient & $p$-Value \\
\hline EDUCATION & $0.021^{* *}$ & 0.044 \\
FEMALE_LABOUR & $0.737^{* *}$ & 0.024 \\
FERTILITY & $-3.107^{* * *}$ & 0.007 \\
DEMOCRACY & $0.081^{* *}$ & 0.030 \\
LABOUR_FORCE & -0.289 & 0.165 \\
TECHNOLOGY & 0.081 & 0.832 \\
COUNTRY & 0.019 & 0.804 \\
CRISIS & $-3.429^{* * *}$ & 0.000 \\
$\mathrm{z}_{1}$ & $131.99^{* * *}$ & \\
$\mathrm{~m}_{2}$ & 0.73 & \\
Hansen & 122.33 & \\
No. observations & 1719 & \\
No. groups & 127 & \\
\hline
\end{tabular}

$z_{1}$ is a Wald test for the reported coefficients of the explanatory variables, asymptotically distributed as $\chi_{2}$ under the null of no relationship for all the explanatory variables. $\mathrm{m}_{2}$ is the second order serial correlation relation in the regression residuals, asymptotically distributed as $N(0,1)$ under the null of no serial correlation. Hansen is a test of the over-identifying restrictions, asymptotically distributed as $\chi_{2}$ under the null of no correlation between the instruments and the error term. Note: ${ }^{* *}$ Statistically significant at the 0.05 level, ${ }^{* *}$ Statistically significant at the 0.01 level.

$\mathrm{H} 2$ must be also confirmed, because if women are more active in the labor force (FEMALE_LABOR), the annual percentage growth rate of GDP increases $(\beta=0.737 ; p=0.024)$. We thus corroborated the most common results already obtained in the previous literature, whereas the evidence against this relationship is scarce.

Our results also support $\mathrm{H} 3$, as the lower female fertility (FERTILITY), the larger the GDP $(\beta=-3.107 ; p=0.007)$, also corroborating results in the economic growth literature.

As found in previous studies [73,74], H4 is also supported, as DEMOCRACY is statically significant $(\beta=0.081 ; p=0.030)$. These results show that the participation of women in the political arena significantly affects the level of economic growth. 
For the control variables, neither labor force nor technology was significant, which does not diminish the validity of the results. In fact, the gender studies quoted in this paper omitted these variables when modelling economic growth, considering only the effects of the gender factors. Similarly, the type of country was not significant. We also tested the significance of other country classifications, such as the origin of their legal system, or other control variables such as the total level of education, and neither were significant and the results did not vary significantly. However, the economic situation was influential, since our analyses revealed that economic crises (CRISIS) have a negative impact on a country's economic growth, as expected $(\beta=-3.429 ; p=0.000)$. Finally, it is also worth mentioning that we considered controlling for the effects of the informal sector, due to its potential impact on economic growth, as shown in $[80,81]$ which noted that the informal sector consists of all activities operating outside the official legal and fiscal system, with a resulting lack of reliable statistical information. In fact, this lack of data represented such a reduction in our sample size, which would have dropped from 1719 to 64 observations as well as in the number of countries (which would have dropped from 127 to 18), that its use as control variable is discouraged.

$$
\begin{gathered}
G D P_{i t}=\beta_{0}+\beta_{1} \text { Education }_{i t}+\beta_{2} \text { FemaleLabor }_{i t}+\beta_{3} \text { Fertility }_{i t}+\beta_{4} \text { Democracy }_{i t}+ \\
+\beta_{5} l_{i t}+\beta_{6} k_{5 i t}+\beta_{7} \text { Country }_{i t}+\beta_{8} \text { Crisis }_{i t}+\eta_{i}+v_{i t}
\end{gathered}
$$

\section{Conclusions}

Interest in studying the different effects of gender in its different dimensions with a multidisciplinary focus has been growing steadily. Given its impact on the economy, the study of female inclusion and gender gaps should not be limited to pay gaps, or their access to the management team, or to the board of directors, which are research topics characteristic of most developed countries. Basic questions that affect all countries should be analyzed, such as the impact of gender on the country's economic growth, regardless of its GDP. If we seek to improve the wellbeing of our citizens, including both men and women, we must all participate together in searching for solutions that do not exclude women. This paper brings together a set of literature that has pursued understanding the factors that determine economic growth. To this list, a set of gender variables have been added, that were studied individually but had not yet been subjected to joint analysis, for such a broad sample, or through accurate and sophisticated econometric methods. These are some of the main contributions of this study. We also wanted to revitalize a subject that the economic crisis had pushed to the background: the role of women in the economic growth of high- and low-income countries.

In this paper, we approached the issue of whether gender gaps (in terms of education, access to the labor market, fertility and fecundity, and democracy) have a significantly negative effect on economic growth. The previous studies on the subject were not conclusive, since authors affirmed that reducing the gap between men and women can significantly stimulate economic growth, whereas others affirmed that its effect is nil or marginal. Our results help to advance the understanding of this issue. In addition, our methodology allowed us to solve the problems of endogeneity, which generated noise in previous studies. This noise impeded definitively concluding whether gender factors affected economic growth or whether the effects were a result of another factor, or the causality was the reverse.

We conclude that the effects on economic growth are positive for the greater access of women to secondary education, access of women to the labor market, and for the active political participation of women. Conversely, a high fertility rate in women has negative effects on economic growth. Besides, as expected, the crisis negatively affected economic growth.

The results mostly coincide with the expected results and with prior evidence in the literature, corroborating the need to demand that politicians and regulators strongly influence the policies of sex education and prevention of pregnancy, especially in low-income countries. Politicians and regulators should also focus on guaranteeing obligatory and free primary and secondary education, and should introduce positive measures that favor the contracting of women in qualified jobs. These measures must be voluntarily demanded by our politicians in the defense of human rights. Reasons of economic 
efficiency should be considered, since, as derived from our analysis, the improvement in education, qualified jobs, and the reduction of pregnancy translate into greater wealth for the country that adopted these positive measures. Moreover, investing in female education would be a waste of resources if women do not have access a qualified job afterwards. This phenomenon requires deeper analysis in future research.

For fertility, our results showed a negative relationship, but we should recall that for some high-income countries, low fertility rates have had perverse effects on economic growth. In many developed countries, fertility rates have radically decreased, often under the sub-replacement threshold, challenging future growth unless migration is favored. In such scenarios, the governments should advocate measures to increase birth rates and promote family life as a way to increase fertility rates and maintain future economic growth and their pension systems.

Access of women to political life was a significant variable in our study, thus, we must make a plea in its favor and encourage governments to increase the number of women in the political arena. In this study, the number of women in politics was very low, with $16 \%$ of women in the governments of 127 countries. Not even one woman was in a top parliamentary management post per country and year of our sample. As previously noted [74], the way to improve gender balance may come " ... from choosing multi-member electoral districts, multi-party systems, and stipulate fixed quotas, since there are findings that countries with multi-member electoral districts, multi-party systems and strict quotas had more female members of parliament than those with flexible quotas and only one or two major political parties". Still, women who reach posts of local, municipal, or national government usually occupy posts of lesser political importance and more of a cultural and social nature $[82,83]$.

Given the above results, we conclude that the existence of the gender gap presents an obstacle for reaching the full economic growth of nations. Not adopting measures that empower women means accepting the existence of those obstacles and impeding obtaining sustained and inclusive economic growth.

Some limitations could affect the relevance of our results, since we used proxies when the proper measurement was not available for variables such as capital formation. Our study was also limited to 127 countries, although the results were representative and easy to generalize. In fact, in order to avoid further reductions in the sample size which may erode the validity and generalization of our results, we did not control for the effects of the informal sector in our model, with the limitations that it may imply. Other questions still remain, which could be analyzed in further research, such as the proportion of female participation necessary to revitalize the economy of a country. To address this question, the objective of our future research is to calculate an index of female empowerment and identify the point from which the effects of the gender gap are negative. Other further lines of research include analyzing the moderating role of gender in other important economic relationships, such as the relationship between the distribution of wealth and economic growth, or the financial inclusion of women and economic growth. Meanwhile, we want to conclude this paper with a call to the public and those in public office to empower women and to enable inclusive economic growth.

Acknowledgments: The authors acknowledge the funding received from the Projects ECO2013-45615-P, ECO2015-63880-R, and ECO2015-69058-R from the Ministerio de Economía y Competitividad of Spain. University of Salamanca is in charge of payment of the open access publication.

Author Contributions: Laura Cabeza-García and Esther B. Del Brio work on gender topics and are experts in panel data methodology, so they were responsible for those areas. Mery Luz Oscanoa-Victorio investigated economic growth and contributed to its modelling and analysis.

Conflicts of Interest: The authors declare no conflicts of interest.

\section{References}

1. Brashaw, S.; Castellino, J.; Diopet, B. Women's Role in Economic Development: Overcoming the Constraints. Sustainable Development Solutions Network. 2013. Available online: http:/ /unsdsn.org/resources/publications / womens-role-in-economic-development-overcoming-the-constraints/ (accessed on 4 December 2017). 
2. Solow, R.M. A Contribution to the Theory of Economic Growth. Q. J. Econ. 1956, 70, 65-94. [CrossRef]

3. Mankiw, N.G.; Romer, D.; Weil, D.N. A Contribution to the Empirics of Economic Growth. Q. J. Econ. 1992, 107, 407-437. [CrossRef]

4. Ministry of Economic Cooperation and Development of Germany. Gender Equality in German Development Policy; BMZ Strategy Paper No. 2; Ministry of Economic Cooperation and Development of Germany: Bonn, Germany, 2014.

5. Schultz, T.P. Human Capital, Family Planning, and their Effects on Population Growth. Am. Econ. Rev. 1994, 84, 255-260.

6. Murthi, M.; Guio, A.C.; Drèze, J. Mortality, Fertility, and Gender Bias in India: A District-Level Analysis. Popul. Dev. Rev. 1995, 21, 745-782. [CrossRef]

7. World Bank. Engendering Development; W.B.: Washington, DC, USA, 2001.

8. Rahman, R.I.; Islam, R. Female Labour Force Participation in Bangladesh: Trends, Drivers and Barriers; ILO Asia-Pacific Working Paper Series No. 14-15; International Labour Organization, DWT for South Asia and Country Office for India: New Delhi, India, 2013.

9. Hakura, D.; Hussain, M.; Newial, M.; Thakoor, V.; Yang, F. Inequality, Gender Gaps and Economic Growth: Comparative Evidence for Sub-Saharan Africa; IMF Working Paper No. 111; International Monetary Fund: Washington, DC, USA, 2016.

10. Barro, R.; Lee, J.W. Sources of Economic Growth. Carnegie-Rochester Conf. Ser. Public Policy 1994, 40, 1-46. [CrossRef]

11. Barro, R.; Sala-i-Martin, X. Economic Growth, 2nd ed.; McGraw-Hill: New York, NY, USA, 1995; ISBN 0-262-02553-1.

12. Licumba, E.A.; Dzator, J.; Zhang, J.X. Gender Equality in Education and Economic Growth in Selected Southern African Countries. In Proceedings of the Australasian Conference on Business and Social Sciences, Sydney, Australia, 13-14 April 2015.

13. Seguino, S. Micro-Macro Linkages between Gender, Development, and Growth: Implications for the Caribbean Region. J. East. Caribb. Stud. 2008, 33, 8-42.

14. King, E.; Hill, M.A. Women's Education in Developing Countries: An Overview. In Women's Education in Developing Countries: Barriers, Benefits and Policies; King, E.M., Hill, M.A., Eds.; Johns Hopkins University Press: Baltimore, MD, USA, 1993; pp. 1-50.

15. Knowles, S.; Lorgelly, P.K.; Owen, P.D. Are Educational Gender Gaps a Brake on Economic Development? Some Cross-Country Empirical Evidence. Oxf. Econ. Pap. 2002, 54, 118-149. [CrossRef]

16. Cuberes, D.; Teignier, M. Gender Inequality and Economic Growth. World Development Report. 2012. Available online: https:/ / openknowledge.worldbank.org/handle/10986/4391 (accessed on 10 July 2014).

17. Qureshi, S.A.; Khan, M.; Rafique, A.; Khan, G.; Wahid, M.S.; Nazli, A. Gender Differential in Education and its Impact on Economic Growth: Pakista in study (1965-2007), a Generalized Method of Moment Approach. Interdiscip. J. Contemp. Res. Bus. 2011, 3, 1310-1317.

18. Dollar, D.; Gatti, R. Gender Inequality, Income and Growth: Are Good Times Good For Women? World Bank Working paper No.1; Development Research Group, The World Bank: Washington, DC, USA, 1999.

19. Forbes, K.J. A Reassessment of the Relationship between Inequality and Growth. Am. Econ. Rev. 2000, 90, 869-887. [CrossRef]

20. Appiah, E.; McMahon, W. The Social Outcomes of Education and Feedbacks on Growth in Africa. J. Dev. Stud. 2002, 38, 27-68. [CrossRef]

21. Klasen, S. Low Schooling for Girls, Slower Growth for All? Cross-Country Evidence on the Effect of Gender Inequality in Education on Economic Development. World Bank Econ. Rev. 2002, 16, 345-373. [CrossRef]

22. Perotti, R. Growth, Income Distribution, and Democracy: What the Data Say. J. Econ. Growth 1996, 1, $149-187$. [CrossRef]

23. Pervaiz, Z.; Chani, M.I.; Jan, S.A.; Chaudhary, A.R. Gender Inequality and Economic Growth: A Time Series Analysis for Pakistan. Middle East J. Sci. Res. 2011, 10, 434-439.

24. Klasen, S.; Lamanna, F. The Impact of Gender Inequality in Education and Employment on Economic Growth in the Middle East and North Africa, Background Paper for Gender and Development in the Middle East and North Africa; W.B.: Washington, DC, USA, 2003.

25. Klasen, S.; Lamanna, F. The Impact of Gender Inequality in Education and Employment on Economic Growth: New Evidence for a Panel of Countries. Fem. Econ. 2009, 15, 91-132. [CrossRef] 
26. Barro, R.; Lee, J.W. International Measures of Schooling Years and Schooling Quality. Am. Econ. Rev. 1996, 86, 218-223.

27. Barro, R.; Sala-i-Martin, X. Economic Growth, 2nd ed.; The MIT Press: Cambridge, MA, USA, 2003.

28. Waseem, M. Gender Inequalities in Education in India: Issues and Challenges. CLEAR Int. J. Res. Commer. Manag. 2015, 6, 68-76.

29. Wolfensohn, J. Women and the Transformation of the 21st Century. In Proceedings of the Fourth UN Conference on Women, Beijing, China, 4-15 September 1995.

30. Kabeer, N.; Natali, L. Gender Equality and Economic Growth: Is there a Win-Win? IDS Working Paper No. 417; Institute of Development Studies: Brighton, UK, 2013.

31. King, E.; Hill, M.A. Women's Education and Economic Well-Being. Fem. Econ. 1995, 1, 21-46. [CrossRef]

32. Ngai, R.; Petrongolo, B. Gender Gaps and the Rise of the Service Economy; IZA Discussion Paper No. 8134; IZA: Hong Kong, China, 2013.

33. Ramanayake, S.S.; Ghosh, T. Role of Gender Gap in Economic Growth: Analysis on Developing Countries versus OECD Countries; Indira Gandhi Institute of Development Research: Mumbai, India, 2017.

34. Moghadam, V. Modernizing Women: Gender and Social Change in the Middle East; Lynne Rienner Publishers: Boulder, CO, USA, 2003.

35. Baliamoune-Lutz, M.; McGillivray, M. Gender Inequality and Growth in Sub-Saharan Africa and Arab Countries? Afr. Dev. Rev. 2007, 21, 224-242. [CrossRef]

36. Elborgh-Woytek, K.; Newiak, M.; Kochhar, K.; Fabrizio, S.; Kpodar, K.R.; Wingender, P.; Clements, B.J.; Schwartz, G. Women, Work, and the Economy: Macroeconomic Gains from Gender Equity; Staff Discussion Note 13/10; International Monetary Fund: Washington, DC, USA, 2013.

37. Klasen, S. Does Gender Inequality Reduce Growth and Development? Evidence from Cross-Country Regressions; World Bank Working Paper No. 7; The World Bank: Washington, DC, USA, 1999.

38. Cavalcanti, T.; Tavares, J. The Output Costs of Gender Discrimination: A Model-Based Macroeconomic Estimate; Discussion Paper No. 6477; Centre for Economic Policy Research: London, UK, 2007.

39. Braunstein, E. Neoliberal Development Macroeconomics: A Consideration of Its Gendered Employment Effects; United Nations Institute for Social Development Research Paper No. 1; United Nations Institute for Social Development: Geneva, Switzerland, 2012.

40. Bloom, D.; Canning, D.; Sevilla, J. The Demographic Dividend: A New Perspective on the Economic Consequences of Population Change; RAND Corporation: Santa Monica, CA, USA, 2003.

41. Bloom, D.; Canning, D.; Fink, G.; Finlay, J. Microeconomic Foundations of the Demographic Dividend; Program on the Global Demography of Aging Working Paper No. 93; Program on the Global Demography of Aging: Cambridge, MA, USA, 2012.

42. Deaton, A.; Paxson, C. The Effects of Economic and Population Growth on National Saving and Inequality. Demography 1997, 34, 97-114. [CrossRef] [PubMed]

43. Lee, R.; Mason, A.; Miller, T. Saving, Wealth, and Population. In Population Matters: Demographic Change, Economic Growth, and Poverty in the Developing World; Birdsall, N., Kelley, A.C., Sindig, S.W., Eds.; Oxford University Press: Oxford, UK, 2001; pp. 137-164.

44. Becker, G.; Duesenberry, J.; Okun, B. An Economic Analysis of Fertility. In Demographic and Economic Change in Developed Countries; Princeton University Press: Princeton, NJ, USA, 1960.

45. Becker, G.; Lewis, G. On the Interaction between the Quantity and Quality of Children. J. Political Econ. 1973, 81, 279-288. [CrossRef]

46. Goldin, C. A Grand Gender Convergence: Its Last Chapter. Am. Econ. Rev. 2014, 104, 1091-1119. [CrossRef]

47. Angelov, N.; Johansson, P.; Lindahl, E. Parenthood and the Gender Gap in Pay. J. Labor Econ. 2016, 34, 545-579. [CrossRef]

48. Kleven, H.; Landais, C. Gender Inequality and Economic Development: Fertility, Education and Norms. Económica 2017, 84, 180-209. [CrossRef]

49. Bloom, D.; Canning, D.; Fink, G.; Finlay, J. Fertility, Female Labor Force Participation, and the Demographic Dividend. J. Econ. Growth 2009, 14, 79-101. [CrossRef]

50. Bloom, D.; Williamson, J. Demographic Transition and Economic Miracles in Emerging Asia. World Bank Econ. Rev. 1998, 12, 419-455. [CrossRef]

51. Ashraf, Q.; Weil, D.; Wilde, J. The Effect of Fertility Reduction on Economic Growth. Popul. Dev. Rev. 2012, 38, 97-130. [CrossRef] [PubMed] 
52. Hartmann, A.M. Fertility and Economic Growth. How does the Fertility Economic Growth in Developing Countries? Master's Thesis, University of Aarhus, Aarhus, Denmark, 2010.

53. Day, C. Economic Growth, Gender Wage Gap and Fertility Rebound. Econ. Rec. 2012, 88, 88-99. [CrossRef]

54. Komura, M. Fertility and Endogenous Gender Bargaining Power. J. Popul. Econ. 2013, 26, 943-961. [CrossRef]

55. Razin, A.; Sadka, E. Population Economics, 1st ed.; The MIT Press: Cambridge, MA, USA, 1995; ISBN 0-262-18160-6.

56. Golosov, M.; Jones, L.E.; Tertilt, M. Efficiency with Endogenous Population Growth. Econometrica 2007, 75, 1039-1071. [CrossRef]

57. Kleven, H.J.; Landais, C.; Søgaard, J.E. Children and Gender Inequality: Evidence from Denmark. Annu. Rev. Econ. 2016, 8, 435-464. [CrossRef]

58. Becker, G.S.; Murphy, K.M.; Tamura, R. Human Capital, Fertility, and Economic Growth. J. Political Econ. 1990, 98, 12-37. [CrossRef]

59. Galor, O.; Weil, D. The Gender Gap, Fertility, and Growth. Am. Econ. Rev. 1996, 85, 374-387. [CrossRef]

60. Lipset, S. Some Social Requisites of Democracy: Economic Development and Political Legitimacy. Am. Political Sci. Rev. 1959, 53, 69-105. [CrossRef]

61. Cutright, P. National Political Development: Measurement and Analysis. Am. Sociol. Rev. 1963, $28,253-264$. [CrossRef]

62. Bollen, K.A. Political Democracy and the Timing of Development. Am. Sociol. Rev. 1979, 44, 572-587. [CrossRef]

63. Huntington, S. The Third Wave: Democratization in the Late Twentieth Century. J. Democr. 1991, 2, 67-68.

64. Bollen, K.A. World System Position, Dependence, and Democracy: The Cross-National Evidence. Am. Sociol. Rev. 1983, 48, 468-479. [CrossRef]

65. Burkhart, R.; Lewis-Beck, M. Comparative Democracy: The Economic Development Thesis. Am. Political Sci. Rev. 1994, 88, 903-910. [CrossRef]

66. Bollen, K.; Jackman, R.W. Income Inequality and Democratization Revisited: Comment on Muller. Am. Sociol. Rev. 1995, 60, 983-989. [CrossRef]

67. Gerring, J.; Kingstone, P.; Lange, M.; Sinha, A. Democracy, History, and Economic Performance: A Case-Study Approach. World Dev. 2011, 39, 1735-1748. [CrossRef]

68. World Development Report: Gender Equality and Development. W.B.: Washington, DC, USA. 2012. Available online: https:/ / openknowledge.worldbank.org/handle/10986/4391 (accessed on 2 August 2014).

69. Massolo, A. Participación de las Mujeres en los Gobiernos Locales de América Latina. Instituto Internacional de Investigaciones y Capacitación de las Naciones Unidas para la Promoción de la Mujer. 2007. Available online: http://www.itson.mx/micrositios/equidad-genero/Documents/participacion_politica_de_las_ mujeres_en_el_ambito_local_2007.pdf (accessed on 14 January 2016).

70. Tong, J. The Gender Gap in Political Culture and Participation in China. Communist Post-Communist Stud. 2003, 36, 131-150. [CrossRef]

71. Balaev, M. Improving Models of Democracy: The Example of Lagged Effects of Economic Development, Education, and Gender Equality. Soc. Sci. Res. 2014, 46, 169-183. [CrossRef] [PubMed]

72. Gerring, J.; Bond, P.; Barndt, W.T.; Moreno, C. Democracy and Economic Growth: A Historical Perspective. World Politics 2005, 57, 323-364. [CrossRef]

73. Jayasuriya, D.S.; Burke, P.J. Female Parliamentarians and Economic Growth: Evidence from a Large Panel. Appl. Econ. Lett. 2013, 20, 304-307. [CrossRef]

74. Xu, L. Effects of Female Political Participation on Economic Growth: Evidence from Asian Countries; Lund University: Lund, Sweden, 2015.

75. Common Wealth Parliamentary Association. Available online: http://www.cpahq.org/cpahq/cpadocs/Library\% 20Note $\% 20-\% 20$ CPA \%20and\%20Role\%20of\%20the\%20Commonwealth.pdf (accessed on 2 August 2014).

76. Arellano, M.; Bond, S. Some Tests of Specification for Panel Data: Monte Carlo Evidence and an Application to Employment Equations. Rev. Econ. Stud. 1991, 58, 277-297. [CrossRef]

77. Löfström, Å. Gender Equality, Economic Growth and Employment. Report for the Swedish Ministry of Integration and Gender Equality. Sweden. 2009. Available online: http:/ /www.forschungsnetzwerk.at/ downloadpub /2009_12_Gender_Equality_study.pdf (accessed on 16 June 2014).

78. Kim, J.; Lee, J.W.; Shin, K.A. Model of Gender Inequality and Economic Growth; ADB Economics Working Paper No. 475; Asian Development Bank: Mandaluyong, Philippines, 2016. 
79. Kleinbaum, D.; Kupper, L.; Muller, K.; Nizan, A. Applied Regression Analysis and Other Multivariate Methods, 3rd ed.; Duxbury Press: Boston, MA, USA, 1998; ISBN 139780871501233.

80. Elgin, G.; Birinci, S. Growth \& Informality: A Comprehensive Panel Data Analysis. J. Appl. Econ. 2016, 19, 271-292. [CrossRef]

81. Mbaye, M.A. The Informal Sector, Growth, Employment \& Sustainable Development; Common Wealth Parliamentary Association: London, UK, 2014.

82. Reynolds, A. Women in the Legislatures and Executives of the World: Knocking at the Highest Glass Ceiling. World Politics 1999, 51, 547-572. [CrossRef]

83. Catalano, A.; Baldez, L. Quotas and Qualifications: The Impact of Gender Quota Laws on the Qualifications of Legislators in the Italian Parliament. Eur. Political Sci. Rev. 2015, 7, 119-144. [CrossRef]

(c) 2018 by the authors. Licensee MDPI, Basel, Switzerland. This article is an open access article distributed under the terms and conditions of the Creative Commons Attribution (CC BY) license (http:/ / creativecommons.org/licenses/by/4.0/). 